\title{
SEROLOGICAL AND MOLECULAR CHARACTERISTICS OF TOMATO MOSAIC TOBAMOVIRUS COAT PROTEIN
}

\author{
Abdelmoamen ${ }^{1}$ A.H., Noha K. El-Dougdoug ${ }^{2}$, El-Borollosy ${ }^{1}$ A.M. \\ and El-Dougdoug ${ }^{1}$ K.A. \\ 1- Agric. Microbiology Dept., Fac. of Agric., Ain Shams Univ., 68 Hadayk Shoubra P.O. Box \\ 11241, Cairo, Egypt \\ 2- Botany Dept., Fac. of Sci., Benha Univ., Qaliobia, Egypt
}

Keywords: ELISA; ToMV; Differential hosts; Coat protein gene; Sero-informatics; Microprecipitin; B-cell epitopes prediction

\begin{abstract}
Plant viruses cause serious disease of crop plants reducing both quality and quantity of final produce. Serological tests are used all over the world in laboratory and field based detection of plant viruses and they are of great indispensable importance in agricultural production; virus certification programs; agricultural quarantine and production of virus-free crops grown for processing or fresh market. Cross reaction between viruses and their strains antisera limits serological differentiation of viruses and their strains by enzyme-linked immunosorbent assay (ELISA). This study aims to characterize the antigenic property of Tomato mosaic virus ToMV coat protein by using some bioinformatic tools to analyze its gene. Therefore, new methods in antibody production could be used as equivalent to Mabs in its high specificity. ToMV isolate was confirmed by Transmission electron microscope and differential hosts and propagated on N. tabacum cv. Samson. Systemic infection was developed on N. tabacum cv. Samson and local infection on Datora metel; D. stramonium; N. glutinosa; Chenopodium amaranticolor; $C$. quinoa. ToMV was purified and used as immunizing agent for antiserum production. TEM showed rod shaped particles with $300 \times 18 \mathrm{~nm}$ dimensions. The titer of produced antiserum was 1:1024 evaluated by microprecipitin test and indirect-ELISA. Coat protein gene was amplified by RT-PCR with expected size of (Approx. $500 \mathrm{bp}$ ). The PCR product was sequenced then the generated nucleotide sequence
\end{abstract}

was translated into 160 amino acids. The amino acid sequence of Five B-cell epitopes, of 14 amino acid residues each, were predicted. Identifying Bcell epitopes play an important role in vaccine design, immunodiagnostic tests, and antibody production. Therefore, computational tools for reliably predicting B-cell epitopes are studied.

\section{INTRODUCTION}

The cultivated tomato (Solanum lycopersicum L.) constitutes a major agricultural industry: it is grown worldwide and, in terms of vegetable crop production, is second only to potato. The viral diseases cause heavy yield losses and are one of the reasons that tomato production has shifted to greenhouses (Hanssen and Lapidot 2012). The major tomato viruses endemic to the Mediterranean basin include Tomato yellow leaf curl virus, Tomato torrado virus, Tomato spotted wilt virus, Tomato infectious chlorosis virus, Tomato chlorosis virus, Pepino mosaic virus, and Tomato mosaic virus (Hanssen and Lapidot 2012). Tobacco mosaic virus (TMV) and Tomato mosaic virus (ToMV) infect several solanaceous species. Cross reaction between ToMV and TMV antisera limits serological differentiation of two viruses by enzyme-linked immunosorbent assay (ELISA) (Jacobi et al 1998). Different diagnostic methods, including DAS-ELISA, multiplex RT-PCR, aphid transmission tests and bioassays, were applied to detect the presence of plant viruses in source and assay plants (Syller and Grupa 2014). Reverse transcriptase-polymerase chain reaction (RT-PCR) is used to identify RNA plant viruses. This procedure is rapid, specific and sensitive, and PCR-based methods are useful in high-throughput applications 
(Walsh et al 2001). The replicase gene of TMV and ToMV is conserved among the viruses of tobamovirus group. Primers were designed for the replicase gene of TMV and ToMV to detect the two viruses individually as well as in mixed infection in pepper and tomato seeds (Kumar et al 2011). This study aims to characterize the ToMV isolate serologically and molecularly.

\section{MATERIALS AND METHODS}

Virus source: Tomato mosaic tobamovirus isolate maintained on $N$. tabacum $\mathrm{cv}$. white burley plants was kindly obtained from Virology lab., Microbiology Dept., Fac. of Agric., Ain Shams Univ. ElDougdoug, (1998). The virus isolate was confirmed by sap inoculation on differential hosts $(N$. glutinosa, N. tabacum cv. Samson, N. Benthamiana, N. rustica, Chenopodium amaranticolor, C. quinoa, Datora metel, and D. stramonium) and serologically by Indirect-ELISA.

Virus propagation: For maintenance of virus isolate, sap from infected plants was extracted in phosphate buffer (100 mM - pH 7.5) at ratio of 1:5 $w / v$ and mechanically inoculated on young leaves of $N$. tabacum cv. Samson predusted with carborundum (600 mesh).

Virus purification: ToMV was purified from systemically infected leaves of $N$. tabacum cv. Samson by the method of (Gooding and Hebert 1967), except that in the final purification step $10-40 \%$ sucrose density gradients were centrifuged at $23000 \mathrm{~g}$ for $2 \mathrm{~h}$. The virus concentration was determined spectrophotometrically by using Shimadzu UV-1800 UV-spectrophotometer on the basis of: $1 \mathrm{~cm} 0.1 \% 260 \mathrm{~nm}=3$, not corrected for light scattering, as the following equation

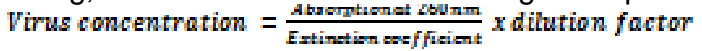

(Bruckman and Steinmetz 2014).

Negative staining: Small drop of purified virus suspension was placed on a 300 mesh carbon coated grids and negatively stained using $2 \%$ uranyl acetate, PH 7.0 according to Christie et al (1987). The grids were examined using the electron microscope JEOL (JEM-2100) TEM in Cairo University Research Park, Faculty of Agriculture, Giza, Egypt.

Immunization of rabbits: Antisera production against ToMV isolate was carried out according to Makkouk and Gumpf, (1975). Two genetically pure adult rabbits, (white New Zealand) with size of 2.5 to $3.0 \mathrm{Kg}$ were used for this experiment. Normal serum was taken as control before the immunization. Purified ToMV isolate was used as antigen to immunize rabbits. The soluble antigen was emulsified with Freund's Incomplete adjuvant (Difco Laboratories Michigan USA), at ratio of 1:1 $\mathrm{v} / \mathrm{v}$ until a stiff white emulsion was formed.

The virus suspension was injected muscularly and intravenously into the two rabbits. Injections were at one week intervals according to the following schedule shown in (Table 1).

Table 1. Immunization schedule of Tomato Mosaic Virus.

\begin{tabular}{|c|c|c|c|c|c|}
\hline$\#$ & Injection site & $\begin{array}{c}\text { Adjuvant } \\
\text { used }\end{array}$ & $\begin{array}{c}\text { Concentration of } \\
\text { virus }\end{array}$ & Dose & $\begin{array}{c}\text { Amount of } \\
\text { virus (mg.) }\end{array}$ \\
\hline 1 & IV & - & $6.175 \mathrm{mg} / \mathrm{ml}$ & $300 \mu \mathrm{l}$ & 1.8525 \\
2 & IM & Incomplete & $2.058 \mathrm{mg} / \mathrm{ml}$ & $900 \mu \mathrm{l}$ & 1.8525 \\
3 & IM & Incomplete & $2.058 \mathrm{mg} / \mathrm{ml}$ & $900 \mu \mathrm{l}$ & 1.8525 \\
4 & IM & Incomplete & $2.058 \mathrm{mg} / \mathrm{ml}$ & $900 \mu \mathrm{l}$ & 1.8525 \\
5 & IM & Incomplete & $2.058 \mathrm{mg} / \mathrm{ml}$ & $900 \mu \mathrm{l}$ & 1.8525 \\
\hline Total & & & & $3900 \mu \mathrm{l}$ & $9.2625 \mathrm{mg}$. \\
\hline
\end{tabular}

$\mathrm{IV}$ = intravenous, IM = Intramuscular, $\mathrm{mg}$. = milligrams

Animal bleeding and serum processing: The rabbit was bled at 10 days after the last injection. Blood was allowed to clot for 2 hrs. at room temperature and was released from the tube by riming with a sterile applicator stick or glass rod. After overnight, refrigeration serum was decanted or aspirated from the clot and centrifuged at 5000 rpm for $30 \mathrm{~min}$. to remove cell debris.

Antisera was stored in deepfreeze at $-20^{\circ} \mathrm{C}$, dispensed as small aliquots in small coated plastic bottle until used for titer determination and the other serological methods (Noordam 1973). 
Antiserum Purification: The produced antiserum was purified by Fractional Ammonium Sulfate Precipitation then dialyzed by the method described by Grodzki and Berenstein, (2010).

\section{Evaluation of produced antiserum}

Slide agglutination: This was carried out according to Van Slogteren, (1969) using produced ToMV Ig and $\left(\mathrm{NH}_{4}\right)_{2} \mathrm{SO}_{4}$ purified antiserum (dilution $1: 2,1: 4,1: 8,1: 16,1: 32$ and 1:64) prepared (using $10 \mathrm{mM}$ Tris- $\mathrm{HCl} \mathrm{pH} 7.2$ ) against Tomato mosaic virus, and normal serum as a control. The amount of precipitate was evaluated according to the following scale: +++ heavy precipitate, ++ moderate precipitate, + slight precipitate, \pm barely visible precipitate, o no precipitate.

Microprecipitin test: This test was done as described by (Noordam 1973), as follows: A $14 \mathrm{~cm}$ glass petri dish was coated with Formvar to make the glass sufficiently hydrophobic. Purified virus suspension of $1 \mathrm{mg} / \mathrm{ml}$ concentration was diluted using Tris- $\mathrm{NaCl}$ buffer $(0.01 \mathrm{M}$ Tris- $\mathrm{HCl} ; 0.85 \%$ $(\mathrm{w} / \mathrm{v}) \mathrm{NaCl})$ at two fold dilutions from: undiluted to 1/128. Two-fold crude antiserum dilution was performed starting from $1 / 16$ to $1 / 1024$. A scheme for the microprecipitin test Fig. (6) was printed so that it had a lattice of $9 \times 8$ squares of $1 \mathrm{~cm}^{2}$. The last column and the last row are labelled B for (buffer). Twelve $\mu$ droplets of Tris- $\mathrm{NaCl}$ buffer were placed in the center of the squares of the column labelled "B". Similarly, $12 \mu \mathrm{l}$ droplets of virus dilutions were placed in all squares of correspondingly labelled columns and this was repeated with buffer and antiserum dilutions, placing the droplets on top of the ones with antigen. The dish cover was placed after lining it with moist filter paper and the dish was incubated at $37^{\circ} \mathrm{C}$ for $2 \mathrm{~h}$. The dish was placed, without cover, on a glossy black background with oblique top light and the drops were examined with a stereomicroscope for the presence of a whitish precipitate at X 16 or X25 magnification. The amount of precipitate was evaluated according to the following scale: +++ heavy precipitate, ++ moderate precipitate, + slight precipitate, \pm barely visible precipitate, o no precipitate.

Indirect Enzyme-linked immunosorbent assay (ELISA): Indirect ELISA was performed as described by Lommel et al (1982). The test was performed by using Nunc-Immuno ${ }^{\mathrm{TM}}$ MicroWell $^{\mathrm{TM}} 96$ well solid flat bottom plates. Three washes were performed between each step of the tests. The rinse solution was $0.15 \mathrm{M} \mathrm{NaCl}$ containing $0.1 \%$ Tween-20 and $0.01 \%$ sodium azide. The initial coating was with antigen at a $1 / 5,000$ dilution (1 $\mu \mathrm{g} / \mathrm{ml}$ ) in $200 \mu \mathrm{l}$ of $0.05 \mathrm{M}$ carbonate, $0.01 \%$ sodium azide, $\mathrm{pH}$ 9.6, for $2 \mathrm{hr}$ at $37 \mathrm{C}$. After washing, the antiviral antibody was then added for $1 \mathrm{hr}$ at 37 C. Produced ToMV Ig as well as IgG from (LOEWE Biochemica ELISA Kit) was used at a 1/1, 1/2, 1/4, $1 / 8,1 / 16,1 / 32,1 / 64,1 / 128,1 / 256,1 / 512,1 / 1024$ and 1/2048 dilutions in "indirect ELISA buffer" (IEB: $0.01 \mathrm{M}$ PBS, pH 7.4, 0.05\% Tween-20, 2\% polyvinylpyrrolidone, and $0.05 \%$ bovine serum albumin). The goat anti-rabbit lgG, coupled with alkaline phosphatase was then added at a 1/ 3,000 dilution in IEB buffer for $1 \mathrm{hr}$ prior to washing and substrate addition. Reactions were recorded $45 \mathrm{~min}$ after the addition of substrate $(300 \mu \mathrm{l}$ of $1 \mathrm{mg} / \mathrm{ml} \mathrm{p}$ nitrophenyl phosphate in $10 \%$ diethanolamine $\mathrm{pH}$ 9.8) at $A_{405} \mathrm{~nm}$ using ELISA reader (BIO RAD iMark $^{\mathrm{TM}}$ Microplate reader). ELISA kit for Tomato mosaic virus was obtained from Agric. Research Center (ARC) provided by (LOEWE Biochemica $\mathrm{GmbH}$ Germany). In order to evaluate the virus in inoculated differential hosts, Indirect-ELISA was done 2 weeks after the inoculation, as mentioned before.

\section{Amplification of coat protein gene (RT-PCR)}

Isolation of total RNA: The total RNA was extracted from $100 \mathrm{mg}$ of the infected $N$. tabacum $\mathrm{cv}$. Samson fresh leaf sample ground in liquid nitrogen according to the Direct-zol ${ }^{\mathrm{TM}}$ RNA MiniPrep (ZYMO Research Corp., CA, USA). The eluted RNA was stored at $-80{ }^{\circ} \mathrm{C}$ for later analysis. Purified RNA was confirmed by UV spectrophotometer and Agarose electrophoresis.

Primer synthesis: Primer sequences were based on the published sequences on genomes of ToMV (accession number KU321698). Two primer pairs were chosen for specific amplification of ToMV coat protein gene ToMV-1 (5'ATGTCTTACTCAATCACTTC3'; forward primer, corresponding to nucleotides 5703-5722 of ToMV) and ToMV-2 (5'ATTTAAGATGCAGGTGCAGA3'; reverse primer, corresponding to nucleotides 61846165 of ToMV) amplifying a 482 bp PCR product (Ge et al 2012).

cDNA synthesis: The cDNA was synthesized using (Qiagen Omniscript ${ }^{\circledR}$ Reverse Transcription Kit) according to the manufacturer in a final volume of $20 \mu \mathrm{l}$. $5 \mu \mathrm{l}$ of total RNA were taken and mixed 
with $2 \mu \mathrm{l}$ of $10 \mu \mathrm{M}$ reverse primer ToMV-2 (5'ATTTAAGATGCAGGTGCAGA3'). Afterwards, the sample were incubated at $70^{\circ} \mathrm{C}$ for $10 \mathrm{~min}$ and quenched on ice for at least $1 \mathrm{~min}$. The other reaction components were added in the following order: $2 \mu \mathrm{l}$ of 10X RT buffer, $2 \mu \mathrm{l}$ dNTP mix, $1.5 \mu \mathrm{l}(20 \mathrm{U})$ of M-MLV reverse transcriptase, and $7.5 \mu$ l RNasefree water. The tubes were incubated for $30 \mathrm{~min}$ at $37^{\circ} \mathrm{C}$ (using Veriti ${ }^{\mathrm{TM}}$ 96-Well Thermal Cycler, Cat. \# 4375786, Applied Biosystems, CA, USA).

RT-PCR: PCR was conducted in $50 \mu$ reaction mixture containing $25 \mu \mathrm{l}$ of $2 X$ GoTaq ${ }^{\circledR}$ Green Master Mix, Cat. \# M7122 (Promega Madison, USA) containing bacterially derived Taq DNA polymerase, dNTPs, $\mathrm{MgCl}_{2}$, two dyes (blue and yellow) that allow monitoring of progress during electrophoresis and reaction buffers at optimal concentrations, $5 \mu \mathrm{l}$ cDNA, $2 \mu \mathrm{l}$ of $10 \mu \mathrm{M}$ of each primer, $16 \mu \mathrm{l}$ nuclease-free water to make up the volume. PCR program was $95^{\circ} \mathrm{C}$ initial melting for 2 min followed by 35 cycles of denaturing at $95^{\circ} \mathrm{C}$ for $30 \mathrm{sec}$, primer annealing at $45^{\circ} \mathrm{C}$ for $30 \mathrm{sec}$, extension at $72^{\circ} \mathrm{C}$ for $30 \mathrm{sec}$ and $72^{\circ} \mathrm{C}$ for $10 \mathrm{~min}$ final extension (using Veriti ${ }^{\mathrm{TM}}$ 96-Well Thermal Cycler, Cat. \# 4375786, Applied Biosystems, CA, USA).

PCR product purification: Amplification product $(4 \mu \mathrm{l})$ was separated on a $1 \%$ agarose gel in $1 \mathrm{X}$ TAE buffer containing $0.5 \mu \mathrm{g} / \mathrm{mL}$ final concentration of ethidium bromide, (usually about 2-3 $\mu$ of lab stock solution per $100 \mathrm{~mL}$ gel) and photographed under UV illumination. A total of $10 \mu \mathrm{l}$ of the amplification product were loaded in the wells. A 100 bp DNA ladder (\#N3231S New England BioLabs ${ }^{\circledR}$ Inc.) was used in the gel to determine the size of the amplified product. The DNA is extracted from the gel using QIAquick Gel Extraction Kit as described in the manufacturer protocol.

Sequence comparison: The sequencing was done on both strands at Macrogen, Korea. Nucleotide sequence was compared with those available in GenBank (https://www.ncbi.nlm.nih.gov), and the amino acid sequence was estimated through the translation tool from Expasy Software (https://www.expasy.org/tools/). Multiple sequence alignments and sequence relationship were produced using CLUSTAL W (Thompson et al 1994), and calculation of percentage of identity was performed by analysis on (http:// bioinformatics.org/ sms/ident sim.html).
Epitopes prediction: The primary amino acids sequence of the ToMV coat protein was evaluated from the corresponding nucleotide sequence using MEGA 6.0 software. The linear B-cell epitopes in the primary amino acid sequence of the coat protein was performed using BCPREDS server with default parameters (http://ailab.ist.psu.edu/bcpred/) which implements a support vector machine (SVM) and the subsequence kernel method (EIManzalawy et al 2008a). Flexible length linear Bcell epitopes were predicted using FBCPred (EIManzalawy et al 2008b) method with a specificity cut-off $75 \%$. The antigenicity of each amino acid residue in the primary protein sequence was determined using a semi-empirical method (Kolaskar and Tongaonkar 1990) which makes use of physicochemical properties of each amino acid and their frequencies of occurrence in experimentally known segmental epitopes.

\section{RESULTS}

TMV isolate confirmation: The data showed that ToMV isolate gave systemic symptoms on $N$. tabacum cv. Samson (Fig. 1). The symptoms were more obvious in younger leaves, which were more newly developed than fully expanded older ones, in the form of leaf malformation (reduction of leaf blade), severe mosaic, and the formation of green blisters. Necrotic local lesions appeared on $D$. metel indicator host (Fig. 1) and gave positive results with ELISA assay (Table 2).

Virus propagation: Infectious sap from maintenance host at 1:5 $\mathrm{w} / \mathrm{v}$ dilution rate was mechanically inoculated on young $N$. tabacum cv. Samson seedlings. Severe mosaic and leaf malformation was observed after 20 days after inoculation with 0.475 OD which gave 153 L.L/100 $\mu$ l Clarified sap on D. metel (Fig. 1).

Virus purification: ToMV was highly purified from systemically infected leaves of $N$. tabacum cv. Samson by the method of (Gooding and Hebert 1967), except that in the final purification step 10$40 \%$ sucrose density gradients were centrifuged at $23000 \mathrm{~g}$ for $2 \mathrm{~h}$. Purification yielded 22.9 milligrams of virus per 100 grams of infected tissue.

Virus morphology: Negatively stained ToMV particles by $2 \%$ Uranyl acetate was investigated using transmission electron microscope. Rod shaped viral particles with length of $300 \mathrm{~nm}$ and 18 $\mathrm{nm}$ width were detected in the highly purified preparation (Fig. 2). 

coat protein

Table 2. Reaction of Tomato mosaic tobamovirus isolate with differential hosts and its optical densities with Indirect-ELISA.

\begin{tabular}{|l|l|c|}
\hline \multicolumn{1}{|c|}{ Differential hosts } & \multicolumn{1}{|c|}{ Symptoms } & $\begin{array}{c}\text { Indirect ELISA } \\
\text { (OD) }\end{array}$ \\
\hline C. amaranticolor & Ch. L. L., large, Irregular, Chlorotic center with hallo & 0.325 \\
C. quinoa & Ch. L. L., Narrow, Regular, Chlorotic center without hallo & 0.354 \\
D. metel & N. L. L., Narrow, Regular, Necrotic center without hallo & 0.412 \\
D. stramonium & N. L. L., Large, Regular, Necrotic center without hallo & 0.301 \\
N. glutinosa & N. L. L., Large, Irregular, necrotic center without hallo & 0.375 \\
N. rustica & Ch. L. L., followed by severe mosaic & 0.489 \\
N. Benthamiana & Ring spots & 0.390 \\
N. tabacum cv. & Severe mosaic & 0.511 \\
Samson & & \\
\hline
\end{tabular}

-ve DAS-ELISA $=0.178 \quad$ +ve DAS-ELISA $=0.495$

Ch. L. L. = Chlorotic local lesion; N. L. L.= Necrotic local lesion
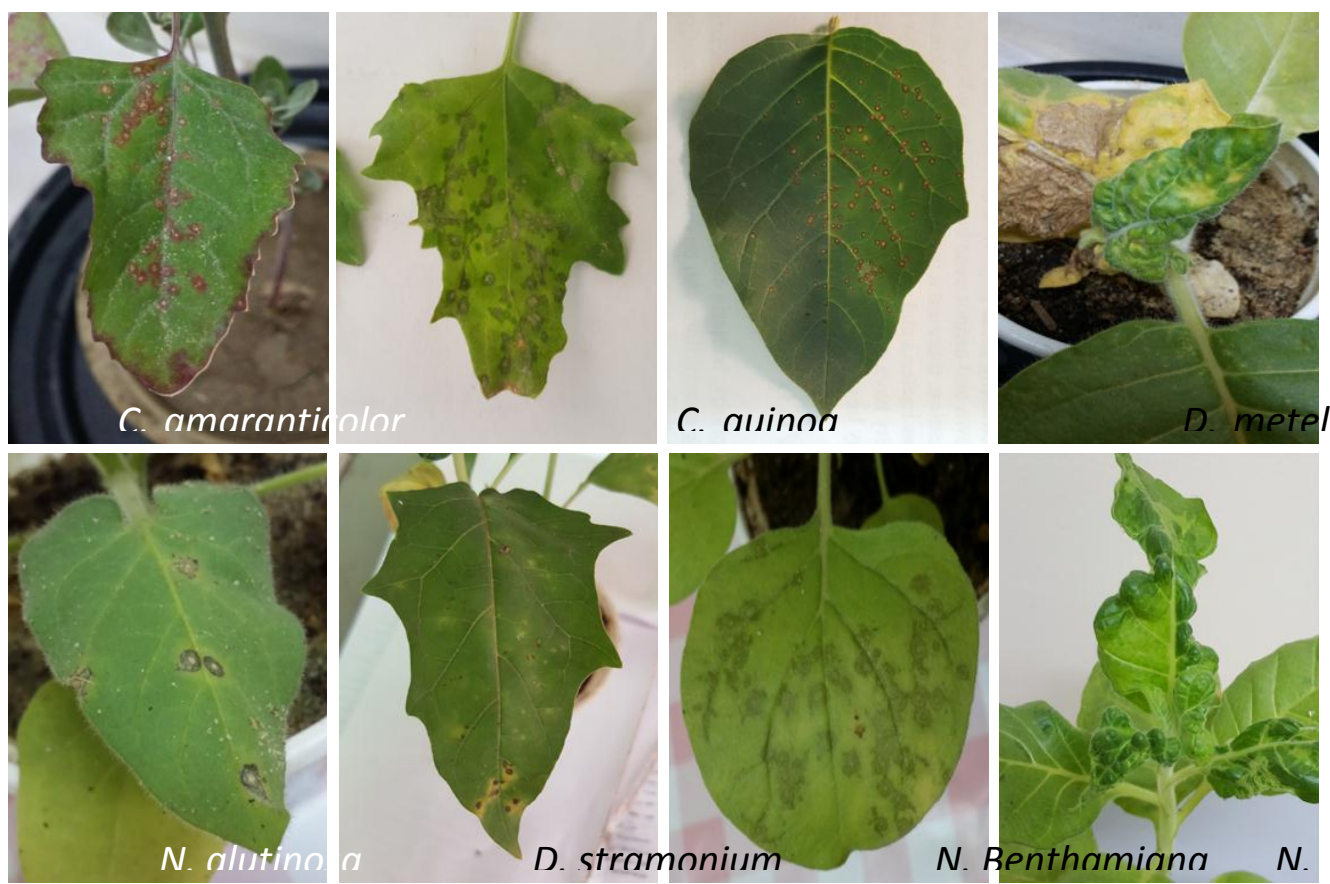

Fig. 1. Reaction of ToMV isolate with differential hosts. 


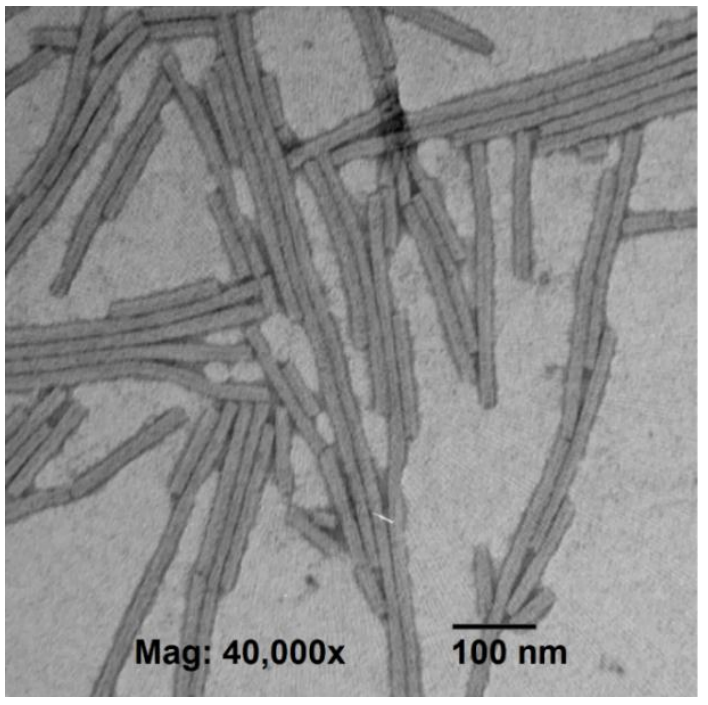

Fig. 2. Photomicrograph of ToMV particles stained with $2 \%$ Uranyl acetate and examined under Transmission Electron Microscope.

Spectrophotometric analysis: The absorption at $260 \mathrm{~nm}$ was 1.032 and the absorption at $280 \mathrm{~nm}$ was 0.843. A260/A280 was calculated and it was equal to 1.224 while, Amin and Amax were measured at $248 \mathrm{~nm}$ and $260 \mathrm{~nm}$ respectively Fig. 3.

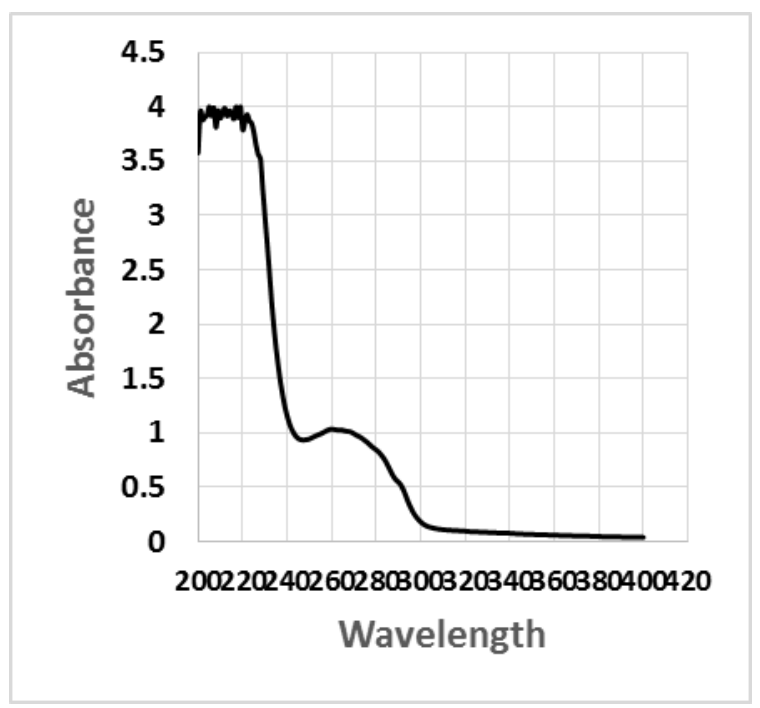

Fig. 3. UV absorbance curve of highly purified ToMV Particles

\section{Evaluation of produced antiserum}

Slide agglutination: The crude infectious sap developed a precipitation reaction with both the crude antiserum and all dilutions tested of purified antiserum. The results were summarized in Table 3. A barely visible precipitate was developed between the crude antiserum and the clarified sap. On the other hand, the best visible reaction was developed between the Clarified sap and the $1^{\text {st }}$ dilution (1:2) of the purified antiserum.

Table 3. The density of precipitation with different antisera dilutions

\begin{tabular}{|c|c|c|c|c|c|c|c|}
\hline $\begin{array}{c}\text { Two fold } \\
\text { dil. of } \\
\text { antiserum }\end{array}$ & $\begin{array}{c}\text { Crude } \\
\text { antiserum }\end{array}$ & $1: 2$ & $1: 4$ & $1: 8$ & $1: 16$ & $1: 32$ & $1: 64$ \\
\hline Reaction & \pm & +++ & +++ & ++ & ++ & ++ & + \\
\hline
\end{tabular}

+++ heavy precipitate, ++ moderate precipitate, + slight precipitate, \pm barely visible precipitate, o no precipitate

Microprecipitin test: a serological whitish precipitation was visible under stereomicroscope between produced ToMV antiserum dilutions and purified virus dilutions $(1 \mathrm{mg} / \mathrm{ml})$. The results were evaluated as mentioned before and summarized in Fig. 5.

The titer of antiserum was 1:1024 and the dilution end point of purified ToMV was 1:32.

\section{Indirect Enzyme-linked immunosorbent assay (ELISA)}

In order to determine an antiserum titration curve, immunoplates were coated with ToMV and a series concentration of antiserum was compared to a negative serum plate. A positive value for the ELISA was defined as the absorbance value (OD405) of two-fold greater than the absorbance of the negative serum. The antiserum titration curve (Fig. 6) shows that the sensitivity of antibodies is clearly at 1:1024 dilution for produced ToMV serum and 1:512 in LOEWE kits IgG.

RNA yield: The total RNA extracted from ToMV infected $N$. tabacum leaves was evaluated before reverse transcription using Qubit 3.0 fluorometer. The concentration of total RNA was $200 \mathrm{ng}$ per $\mu \mathrm{l}$. Then overall RNA quality and yield was assessed by electrophoresis on $1 \%$ agarose gel. RNA fragments appeared intact on the gel and had sharp $28 \mathrm{~S}$ and $18 \mathrm{~S}$ rRNA bands. The $28 \mathrm{~S}$ rRNA band was approximately twice as intense as the $18 \mathrm{~S}$ rRNA band (Fig. 7). This 2:1 ratio (28S:18S) indicated the success of total RNA extraction with high density. 

coat protein

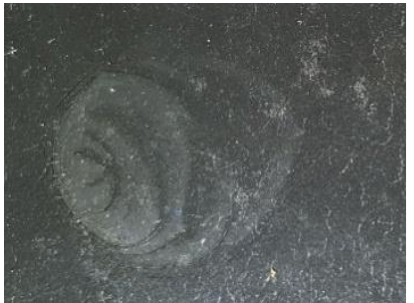

Normal serum +
Clarified sap of in-
fected leaf

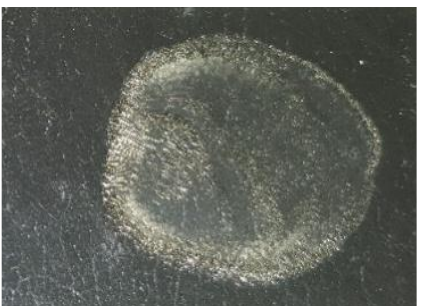

Crude antiserum + Clarified sap

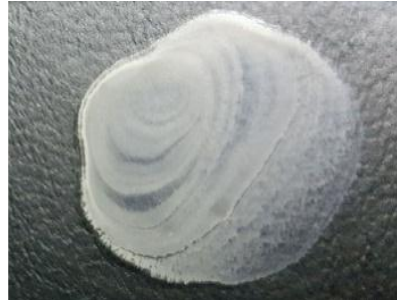

Purified Ig (1:2) + Clarified sap

Fig. 4. The difference in the whitish precipitate occurred between clarified ToMV sap with crude antiserum and purified antiserum
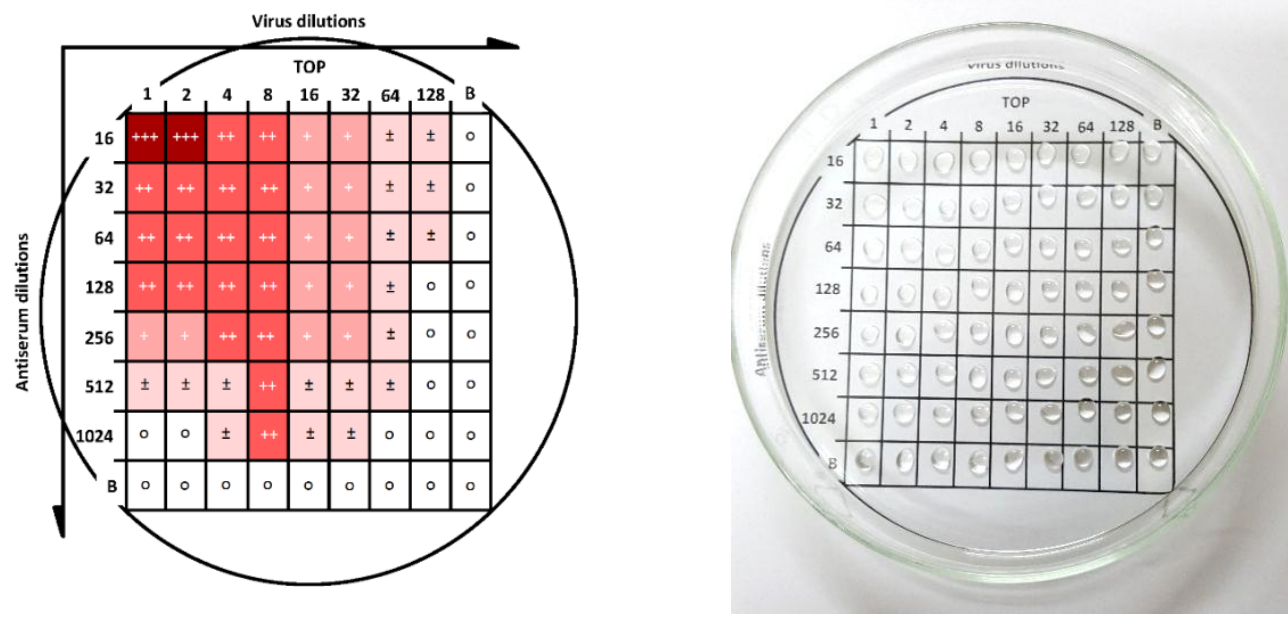

Fig. 5. Microprecipitin test with ToMV. The dark colors or $(+++)$ and $(++)$ represents a heavier precipitation while the faint colors or $(+)$ and $( \pm)$ represents slight precipitation and barely visible precipitate

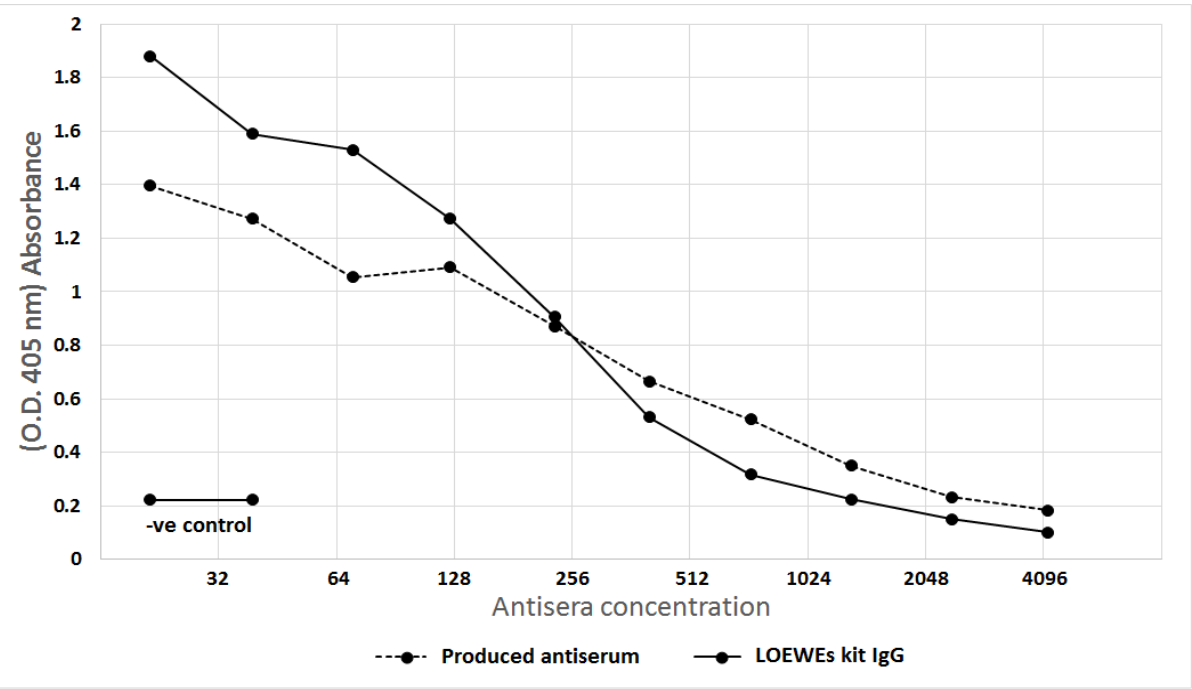

Fig. 6. Indirect ELISA titration of the produced ToMV antiserum 


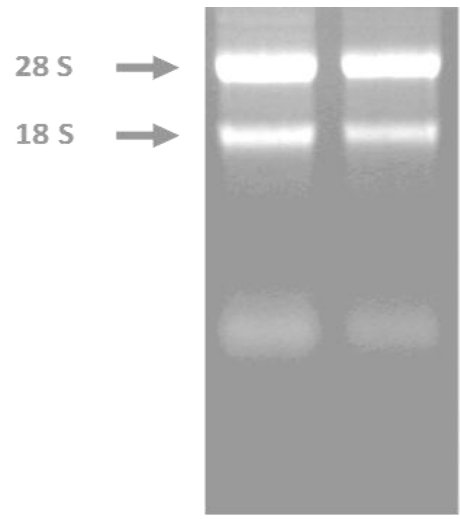

Fig. 7. Intact total RNA. Two $\mu \mathrm{g}$ of intact total RNA were run beside A 100 bp DNA ladder on a $1 \%$ denaturing agarose gel. The $18 \mathrm{~S}$ and $28 \mathrm{~S}$ ribosomal RNA bands are clearly visible in the intact RNA sample.

cDNA synthesis: The total RNAs from ToMV infected $N$. tabacum leaves was reverse transcribed by RT-PCR using the one oligonucleotide downstream primer for ToMV-CP gene. On the other hand, no transcription has done with the healthy one.

Amplification of cDNA: The viral cDNA was amplified by PCR using the two oligonucleotides downstream (Reverse) and upstream (Forward) primers for ToMV-CP gene. The size of the amplified PCR product of ToMV-CP gene was estimated at (500 bp) by comparing its electrophoretic mobility beside A 100 bp DNA ladder as shown in (Fig. 8).

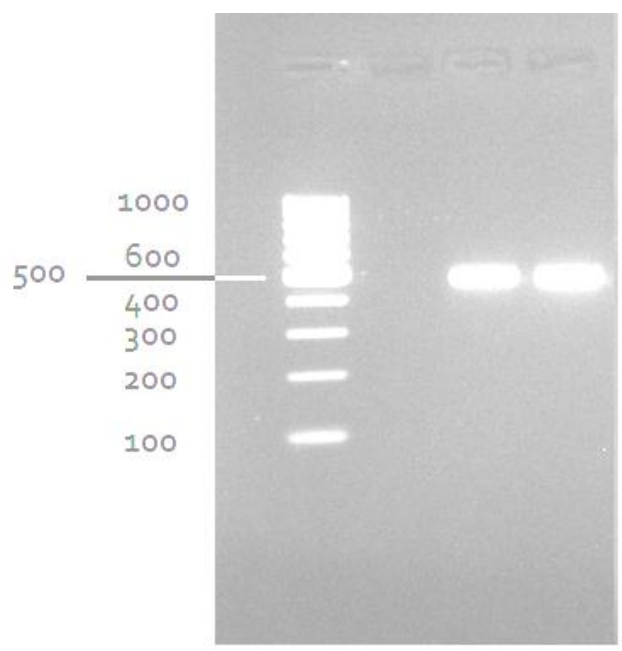

Fig. 8. Agarose gel electrophoresis (1\%) stained by ethidium bromide. Showing analysis of RT-PCR amplified product
Nucleotide sequence analysis: The partial sequence of the PCR-amplified fragment for CP gene of ToMV isolate was done to determine the genetic relationship with other recommended isolates in the gene bank and to conduct further bioinformatic analysis. The sequencing was done on both strands at Macrogen, Korea. The cDNA sequence was performed using the produced PCR products when the specific (downstream and upstream) primers for CP gene of ToMV were used.

Total count of nucleotides as shown in Fig. 9 was found to be (483 bp). The CP gene of ToMV revealed the highest content for Thymine (T) 143 (29.6\%) followed by Adenine (A) 142 (29.4\%), then Guanine (G) $102(21.1 \%)$ and finally Cytosine (C) $96(19.8 \%)$ while \%G-C content was found to be $41 \%$.

The partial nucleotide sequence of ToMV coat protein gene was aligned with ten isolates of ToMV in the Gene bank according to the $E$ value as shown in Table 4.

Phylogenetic tree illustrating relationships based on multiple alignments of $\mathrm{CP}$ gene amino acid sequence of our isolate and other isolates in the gene bank indicated that the studied ToMV isolate have $100 \%$ identity with potato 1 isolate from korea and $99 \%$ identity with other four isolates (S5, ToMV1-2, DSMZ PV-127, ToMV3 and S2), while it had the least identity $97 \%$ with (AH5 and $\mathrm{AH} 1$ ) isolated from Egypt. This is probably due to geographic translocation of the Korean isolate to Egypt.

Coat protein gene was amplified by RT-PCR with expected size of (483 bp). For prediction of the linear B-cell epitopes in the ToMV coat protein primary amino acids sequence, BCPREDS server was used. Five epitopes, whose sequence length was 14 residues, were retrieved (Table 5). The highest epitope according to specificity was LNVCTNSLGNQFQT Followed by RIIEVENQQNPTTA while VQQQFSEVWKPFPQ was the lowest specific. The epitopes were displayed on the amino acids sequence as well as highlighted on the 3-dimensional structure of the coat protein of ToMV as shown in (Figure 11).

The antigenicity profile of the amino acid residues of the coat protein demonstrated the residue of high frequency to be part in the genetic determinant. The highest residues above the threshold value were numerous such as Valine $(V)$, Leucine $(L)$, Glycine (G), Glutamine $(Q)$, serine (S) and Cytosine (C) with antigenicity score and spanning the region $25-40,93-110$, and 138-152 in the 
ATGTCTTACTCAATCACTTCTCCATCGCAATTTGTGTTTTTGTCATCTGTATGGGCTGACCCTATAGAATTGTTAAACGTTTGTACAAATTCGTTAGGTAACCAGTTTCAAACACAGCAAGCAAGAACTACTGTTCAACAGCAGTTCAGCGAGGTGTGGAAACCTTTCCCTCAGAGCACCGTCAGATTTCCTGGCGATGTTTATAAGGTGTACAGGTACAATGCAGTTTTAGATCCTCTAATTACTGCGTTGCTGGGGTCTTTTGATACTAGGAATAGAATAATCGAAGTAGAAAACCAGCAGAATCCGACAACAGCTGAAACGTTAGATGCTACCCGCAGGGTAGACGACGCTACGGTTGCAATTCGATCTGCTATAAATAATTTAGTTAATGAACTAGTAAGAGGTACTGGACTATACAATCAAAATACTTTTGAAAGTATGTCTGGGTTGGTCTGGACCTCTGCACCTGCATCTTAAATG

Fig. 9. Partial nucleotide sequence of ToMV CP gene counted $483 \mathrm{bp}$.

Table 4. ToMV isolates used for sequence comparative analysis with the present isolate

\begin{tabular}{|c|c|c|c|c|c|}
\hline Isolate & Host & Isolated from & Accession & Identity & E value \\
\hline potato1 & Solanum tu- & Korea & AAF70335 & $100 \%$ & $3 \mathrm{e}-100$ \\
S55 & perosum & Spain & AEO16780 & $99 \%$ & $1 \mathrm{e}-99$ \\
ToMV1-2 & Tomato & England & ABJ16498 & $99 \%$ & $3 \mathrm{e}-99$ \\
DSMZ PV-127 & Tomato & Germany & CAD22082 & $99 \%$ & $4 \mathrm{e}-99$ \\
ToMV3 & Nicotiana tabacum & Brazil & AND74056 & $98 \%$ & $7 \mathrm{e}-99$ \\
T15 & Tomato & Spain & AEO11808 & $98 \%$ & $7 \mathrm{e}-99$ \\
AH5 & Tomato & EGYPT & CEZ26286 & $97 \%$ & $8 \mathrm{e}-99$ \\
S2 & pepper & Spain & AEO16779 & $99 \%$ & $9 \mathrm{e}-99$ \\
Ker.Pep.38 & pepper & Iran & AFZ62504 & $98 \%$ & $1 \mathrm{e}-98$ \\
AH1 & Tomato & EGYPT & CEZ26278 & $97 \%$ & $1 \mathrm{e}-98$ \\
\hline
\end{tabular}

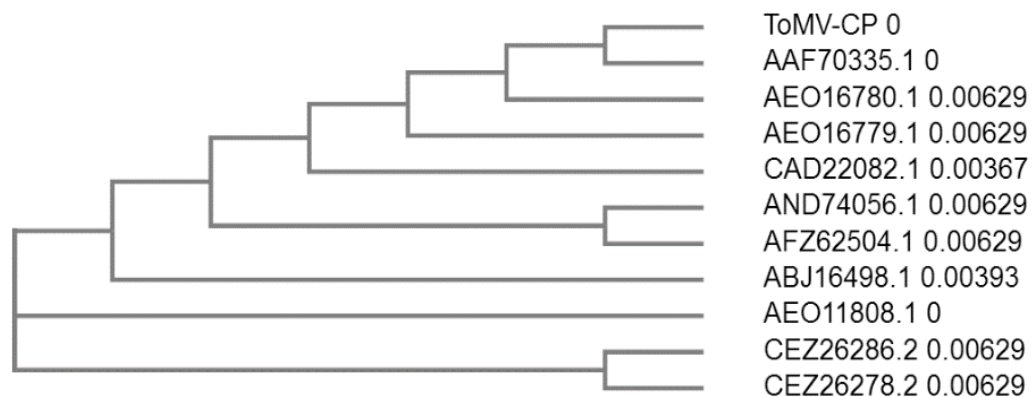

Fig. 10. Cladogram constructed from the multiple alignment of the amino acid sequences using Simple Phylogeny tool (https://www.ebi.ac.uk) (Kimura, 1980; Li et al 2015) representing the relationship between our ToMV isolate and recommended isolates in the gene bank

Table 5. FBCPred Predictions of epitopes in the amino acids sequence of ToMV coat protein

\begin{tabular}{|c|c|c|}
\hline Position & Epitope & Score \\
\hline 25 & LNVCTNSLGNQFQT & 0.999 \\
93 & RIIEVENQQNPTTA & 0.998 \\
138 & GLYNQNTFESMSGL & 0.97 \\
65 & GDVYKVYRYNAVLD & 0.967 \\
45 & VQQQFSEVWKPFPQ & 0.929 \\
\hline
\end{tabular}




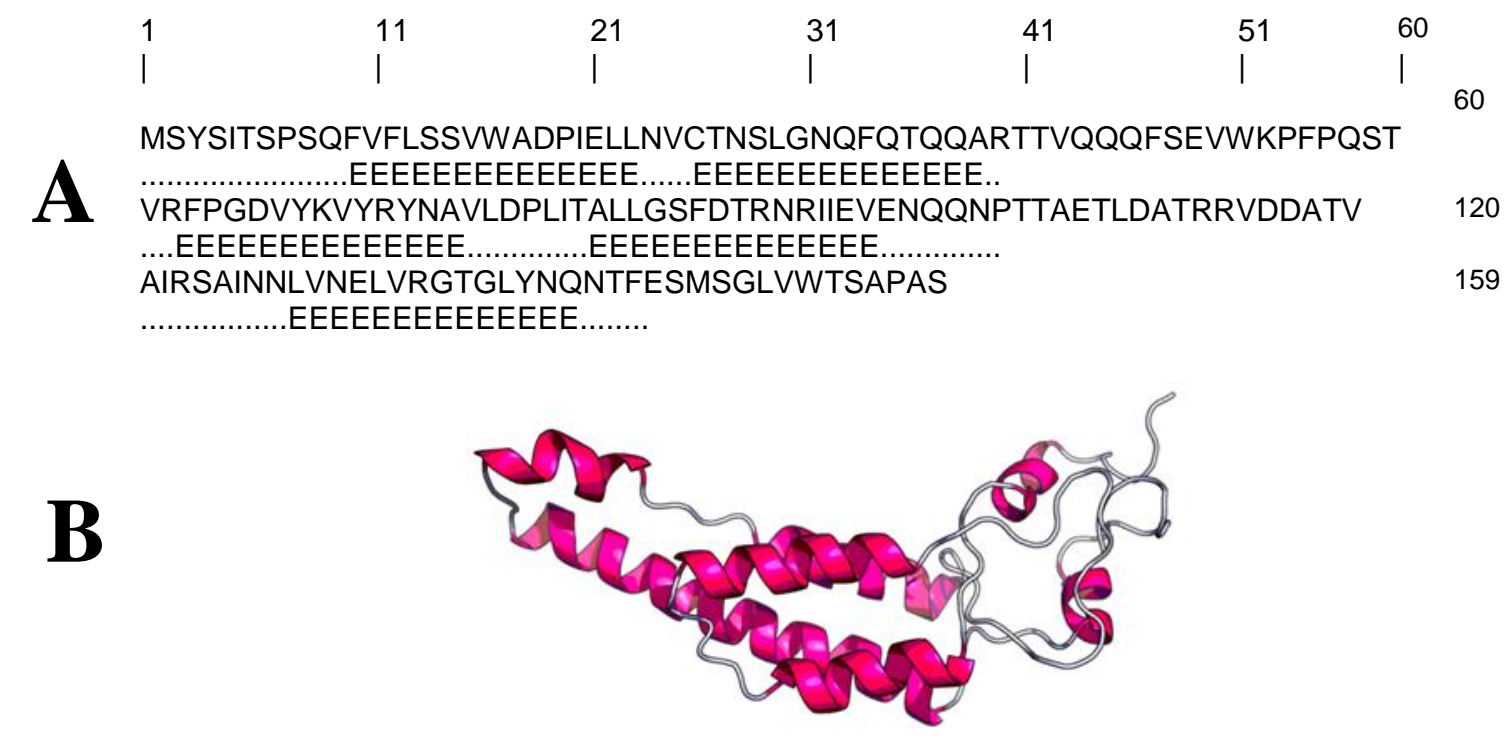

Fig. 11. (A) Amino acid residues of ToMV coat protein predicted as epitopes (Helix) are highlighted. (B) 3dimentional structure of ToMV coat protein showing the position of the predicted epitope (Helix) on the surface of the protein (Filament).

primary protein sequence. These residues with high frequencies of occurrences in antigenic determinants were highlighted (yellow) in the antigenicity profile (Fig. 12).

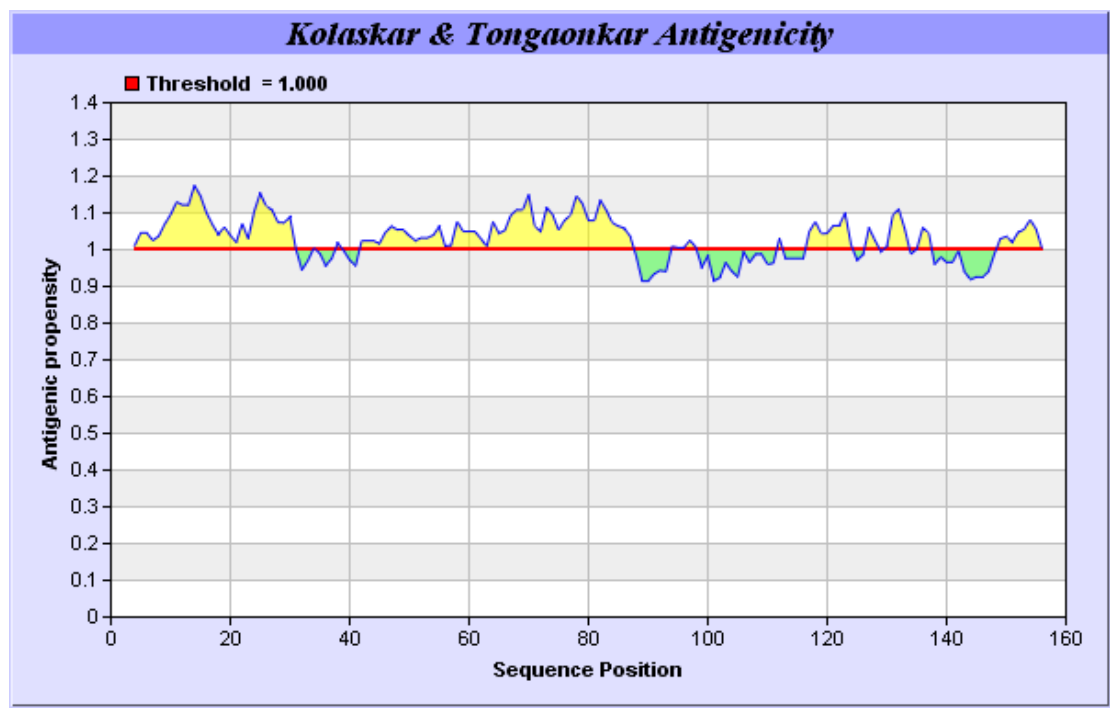

Fig. 12. Kolaskar and Tongaonkar antigenicity scale for prediction of antigenic determinants in ToMV coat protein. Amino acid residues of high frequencies in epitopes are distinguished (yellow) 


\section{Serological and molecular characteristics of tomato mosaic tobamovirus coat protein}

\section{DISCUSSION}

ToMV isolate was identified and confirmed: (a) Biologically by studying the reaction of some differential hosts, (b) Microscopically by examining virus particles morphology under TEM (c) Serologically by EIISA and (d) Molecularly by RT-PCR. This simple work can be used to identify virus strains (Ellis et al 1997; El-Ahdal et al 2007).

Differential hosts and symptomatology: ToMV isolate used in this study was found to give chlorotic local lesions on $C$. amaranticolor and $C$. quinoa whilst it gave necrotic local lesions on $N$. glutinosa, $D$. metel and $D$. stramonium. Concerning $N$. rustica it gave also chlorotic lesions on inoculated leaves then systemic symptoms in the form of severe mosaic and leaf malformation. Severe mosaic and malformation were produced on $N$. tabacum cv. Samson plants, whereas the formation of ringspots is clear on N. Benthamiana. These findings are in agreement with (El-Ahdal et al 2007).

Tobacco mosaic virus (TMV) and Tomato mosaic virus (ToMV) infect several solanaceous species. Both viruses produce local lesions on Nicotiana glutinosa and Nicotiana tabacum cv. Xanthi. The two viruses could be differentiated based on the symptoms on Nicotiana sylvestris and N. tabacum cv. White Burley: TMV produces systemic infection in both these hosts, whereas ToMV produces only local lesions (Green et al 1987).

The systemic symptoms were more obvious in younger leaves, which were more newly developed than fully expanded older ones, in the form of malformation (reduction of leaf blade), severe mosaic, formation of green blisters, vein banding, dwarfing and deformation.

Transmission Electron Microscope Examination: Examination of electron micrographs showed minimum amount of host components compared with preparations obtained from leaves, in addition virus particles were easily measured in negatives of preparation obtained from sucrose gradient for the mentioned reason and for the low number of fragmented particles. Model dimensions were found to be $300 \times 18 \mathrm{~nm}$. These lengths were in accordance with (Bruckman and Steinmetz 2014).

UV absorption: The A260/A280 ratio for purified ToMV virus suspension was found to be equal to the previously published ratio (1.2) which indicates intact ToMV particles. This finding is in agreement with (Bruckman and Steinmetz 2014).

Serological discrimination was evaluated via slide agglutination, microprecipitin and Indirect ELISA tests. Polyclonal antibody was used and the antigenic prosperities were similar for ToMV isolates and reveal no change due to ecological factors and stability of these antigens.

Slide agglutination: This test was found to be a simple and rapid method for serological detection of ToMV and other viruses and could be practically used to rapidly detect many viruses in field. The test gave positive results in the form of precipitation with crude sap extracted from tobacco leaves 20 days post mechanical inoculation. The reaction was more clear with higher lg concentration which can be used to increase the sensitivity of the test. This test was used before for rapid detection of TMV (DOUNIN and POPOVA 1937).

The microprecipitin test is economical in its use of antiserum and is fairly sensitive since small precipitates are easily detected under the microscope. The method has been used extensively in the diagnosis of virus diseases and for large scale indexing of vegetative propagation material (Van Regenmortel 1982). A similar precipitation pattern was obtained in this experiment as Noordam, (1973) found with Tobacco Necrosis virus.

TMV and ToMV are closely related. Both viruses infect pepper, potato, tomato and several other hosts including weeds. Diagnosis of the pathogen plays an important role in crop improvement and disease management strategies. The PCR-based molecular detection of phytopathogenic viruses is gaining importance in recent years. Biological assays, serological detection and identification of species within the genus tobamovirus can be time consuming and might lead to ambiguous results, especially for TMV and ToMV. Differentiation problems are caused by heterologous reactions of antisera detecting common epitopes as well as by antisera produced against virus mixtures (Letschert et al 2002). The multiplex RT-PCR technique allows rapid detection and differentiation of TMV and ToMV. The multiplex RT-PCR is also applicable to detect and differentiate TMV and ToMV in major solanaceous hosts such as tobacco, tomato and pepper. In addition, it is a quick screening mechanism for unknown isolates of TMV, ToMV or both and verifies the authenticity of virus stock cultures in leaf material or purified virus preparations. Earlier Jacobi et al (1998) used pri- 
mer from the coat and movement protein coding regions to detect and differentiate ToMV and TMV. Molecular techniques such as multiplex RT-PCR and RT-PCR using species-specific primers were proven to be useful for the diagnosis and control of the disease and will also be beneficial for resistance breeding, epidemiological investigations and plant virus collections.

Intact total RNA run on a denaturing gel will have sharp $28 \mathrm{~S}$ and 18S rRNA bands (eukaryotic samples) as shown in Fig. 7. The $28 \mathrm{~S}$ rRNA band should be approximately twice as intense as the 18S rRNA band. This $2: 1$ ratio (28S:18S) is a good indication that the RNA is intact. Partially degraded RNA will have a smeared appearance, will lack the sharp rRNA bands, or will not exhibit a 2:1 ratio. Completely degraded RNA will appear as a very low molecular weight smear. Inclusion of RNA size markers on the gel will allow the size of any bands or smears to be determined and will also serve as a good control to ensure the gel was run properly. (Skrypina 2003).

The characterization of B-cell epitopes using computational tools is highly desirable. The epitopes prediction saves time and labor for validation experiments. The identification of epitopes plays a key role in the antibody production, vaccine design as well as immunodiagnostic testing (Sette and Fikes 2003). In this study, BCPREDS server was used to predict epitopes found in the primary amino acids sequence of ToMV coat protein. BCPREDS was used before to predict linear B-cell epitopes in SARS-CoV S protein and demonstrated potential value in clinical applications (EIManzalawy et al 2008a). There was a large variability in the length and numbers of epitopes among the different proteins analyzed. Here, a fixed length of epitopes (14 residues) was observed. In previous studies, peptide sequences of length 20 and shorter were examined in epitope identification experiments (Saha and Raghava 2006). In the same study, the 16-mer peptides worked as optimal sequences. The epitope prediction has many implications in virus detection and differentiation applications. Monoclonal antibodies against synthetic peptides from the predicted amino acids sequence of ToMV coat protein were designed before and used for ToMV strain differentiation (Ounouna et al 2002).

The antigenicity profile of ToMV coat protein revealed that the hydrophobic residues such as Cysteine, Leucine, Glycine, Glutamine and Valine are more likely to be present on the surface of the coat protein and do have a hierarchy signature and be part of the genetic determinants (Mine and Wei Zhang 2002; Aftabuddin and Kundu 2007). The presence of isoleucine, glutamine, glycine and glutamic acid in the epitopes of ToMV coat protein were reported as critical residues for the recognition by monoclonal antibodies (Tian et al 2014).

\section{REFERENCES}

Aftabuddin, M. and Kundu, S. 2007. Hydrophobic, Hydrophilic, and Charged Amino Acid Networks within Protein. Biophys. J. 93, 225-231. doi: 10.1529/biophysj.106.098004

Bruckman, M.A. and Steinmetz, N.F. 2014. Chemical Modification of the Inner and Outer Surfaces of Tobacco Mosaic Virus (TMV). Methods Mol Biol 1108, 173-185. doi: 10.1007/978-1-62703-751-8_13

Christie, S.R., Purcifull, D.E., Crawford, W.E. and Ahmed, N.A. 1987. Electron microscopy of negatively stained clarified viral concentrates obtained from small tissue samples with appendices on negative staining techniques. Bull. Agric. Exp. Station. Univ. Florida USA 45 p.

Dounin, M.S. and Popova, M.N.N. 1937. The drop method of virus diagnosis in plant husbandry. State Publ. Off. Lit. collect, coop. Farming "Selkhozgiz", Moscow

El-Ahdal, A.M.E., Mayer, F., El-Afifi, S.I. and Allam, E.K. 2007. Characterization of two strains of Tobacco Mosaic Virus by biological, biochemical, immunological and electron microscopical techniques. Z. Allg. Mikrobiol. 24,507-514. doi: 10.1002/jobm.19840240802

El-Manzalawy, Y., Dobbs, D. and Honavar, V. 2008a. Predicting linear B-cell epitopes using string kernels. J. Mol. Recognit. 21, 243-255. doi: $10.1002 / j m r .893$

El-Manzalawy, Y., Dobbs, D. and Honavar, V. 2008b. Predicting flexible length linear B-cell epitopes. Comput. Syst. Bioinformatics Conf. 7, 121-32. doi: 10.1002/jmr.893

Ellis, P., Stace-Smith, R. and de Villiers, G. 1997. Identification and Geographic Distribution of Serotypes of Potato Virus Y. Plant Dis. 81, 481-484. doi: 10.1094/PDIS.1997.81.5.481

Ge, B.-B., Liu, G.J. and Wang, H.Q. 2012. First Report of Tomato mosaic virus Infecting Pepino in China. Plant Dis. 96, 1704-1704. doi: 10.1094/PDIS-05-12-0475-PDN

Gooding, G.V. and Hebert, T.T. 1967. A simple technique for purification of tobacco mosaic virus in large quantities. Phytopathology 57, 1285-1286. 

coat protein

Green, S., Hwang, L. and Kuo, Y. 1987. Epidemiology of tomato mosaic virus in Taiwan and identification of strains. J. Plant Dis. Prot. 94, 386-397.

Grodzki, A.C. and Berenstein, E. 2010. Antibody Purification: Ammonium Sulfate Fractionation or Gel Filtration. In: Immunocytochemical Methods and protocols, Humana Press, New york, USA. pp 15-26.

Hanssen, I.M. and Lapidot, M. 2012. Major Tomato Viruses in the Mediterranean Basin. In: Loebenstein G, Lecoq H (eds) Advances in Virus Research, Volume 84, Viruses and Virus Diseases of Vegetables in the Mediterranean Basin, Academic Press, Cambridge, massachusetts, USA. pp 31-66.

Jacobi, V., Bachand, G.D., Hamelin, R.C. and Castello, J.D. 1998. Development of a multiplex immunocapture RT-PCR assay for detection and differentiation of tomato and tobacco mosaic tobamoviruses. J. Virol. Methods 74,167-78.

Kimura, M. 1980. A simple method for estimating evolutionary rates of base substitutions through comparative studies of nucleotide sequences. J. Mol. Evol. 16, 111-120. doi: 10.1007/bf01731581

Kolaskar, A.S. and Tongaonkar, P.C. 1990. A semi-empirical method for prediction of antigenic determinants on protein antigens. FEBS Lett. 276, 172-174. doi: 10.1016/00145793(90)80535-Q

Kumar, S., Udaya Shankar, A.C., Nayaka, S.C. and Prakash, H.S. 2011. Detection of Tobacco mosaic virus and Tomato mosaic virus in pepper and tomato by multiplex RT-PCR. Lett. Appl. Microbiol. 53, 359-363. doi: 10.1111/j.1472-765X.2011.03117.x

Letschert, B., Adam, G., Lesemann, D.E. and Heinze, C. 2002. Detection and differentiation of serologically cross-reacting tobamoviruses of economical importance by RT-PCR and RTPCR-RFLP. J. Virol. Methods 106, 1-10. doi: 10.1016/S0166-0934(02)00135-0

Li, W., Cowley, A., Uludag, M. and Lopez, R. 2015. The EMBL-EBI bioinformatics web and programmatic tools framework. Nucleic Acids Res. 43,W580-4. doi: 10.1093/nar/gkv279

Lommel, S., McCain, A. and Morris, T. 1982. Evaluation of indirect enzyme-linked immunosorbent assay for the detection of plant viruses. Phytopathology 72, 1018-1022.

Makkouk, K.M. and Gumpf, D.J. 1975. Characterization of Potato Virus $Y$ Strains Isolated from Pepper. Phytopathology 66, 576-581.
Mine, Y. and Wei Zhang, J. 2002. Identification and Fine Mapping of $\lg G$ and $\lg E$ Epitopes in Ovomucoid. Biochem. Biophys. Res. Commun. 292, 1070-1074. doi: 10.1006/bbrc.2002.6725

Noordam, D. 1973. Identification of plant viruses. Methods and experiments. Potato Res 17, 234. doi: 10.1007/BF02360391.

Ounouna, H., Kerlan, C., Lafaye, P. and EIGaaied, A. 2002. Production of monoclonal antibodies against synthetic peptides of the $\mathrm{N}$ terminal region of Potato virus $\mathrm{Y}$ coat protein and their use in PVY strain differentiation. Plant Pathol. 51, 487-494. doi: 10.1046/j.1365-3059.2002.00734.x

Saha, S. and Raghava, G.P.S. 2006. Prediction of continuous B-cell epitopes in an antigen using recurrent neural network. Proteins 65,,40-48. doi: 10.1002/prot.21078

Sette, A. and Fikes, J. 2003. Epitope-based vaccines: an update on epitope identification, vaccine design and delivery. Curr. Opin. Immunol. 15, 461-470. doi: 10.1016/S09527915(03)00083-9

Skrypina, N. 2003. Total RNA suitable for molecular biology analysis. J. Biotechnol. 105, 1-9. doi: 10.1016/S0168-1656(03)00140-8

Syller, J. and Grupa, A. 2014. The effects of coinfection by different Potato virus $Y$ (PVY) isolates on virus concentration in solanaceous hosts and efficiency of transmission. Plant Pathol. 63, 466-475. doi: 10.1111/ppa.12095

Thompson, J.D., Higgins, D.G. and Gibson, T.J. 1994. CLUSTAL W: improving the sensitivity of progressive multiple sequence alignment through sequence weighting, position-specific gap penalties and weight matrix choice. Nucleic Acids Res. 22, 4673-4680.

Tian, Y.P., Hepojoki, J., Ranki, H. and Valkonen, J.P.T. 2014. Analysis of Potato virus $Y$ Coat Protein Epitopes Recognized by Three Commercial Monoclonal Antibodies. PLoS One 9,e115766. 10.1371/journal.pone.0115766

Van Regenmortel, M.H.V. 1982. Serological Techniques. In: Serology and Immunochemistry of Plant Viruses. Elsevier, netherlands, pp. 73-133.

Van Slogteren, D.H.M. 1969. Analytical serology of plant viruses (phytophagineae). In: Kwapinski JBG (ed) Analytical serology of microorganisms, $1^{\text {st }}$ Ed. Wiley, New York, USA, pp. 353-409.

Walsh, K., North, J., Barker, I. and Boonham, N. 2001. Detection of different strains of Potato virus $Y$ and their mixed infections using competitive fluorescent RT-PCR. J. Virol. Methods 91, 167-73. 
